
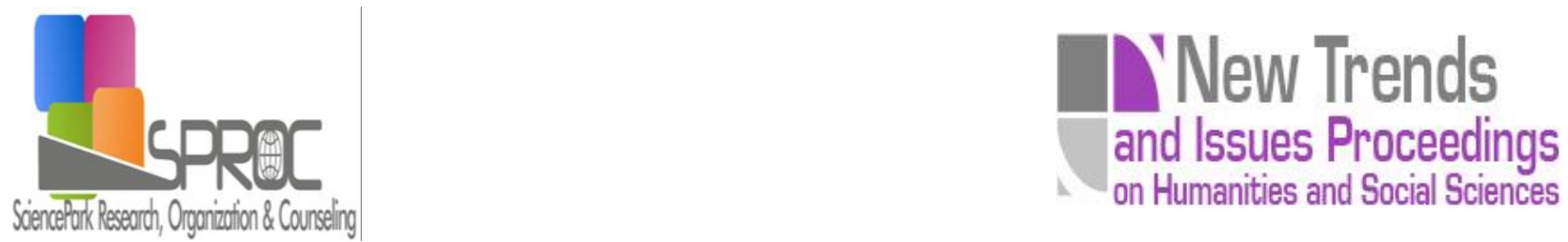

\title{
The Effects of Generating Questions and Raising Discussion on L2 Critical Reading
}

\author{
Nasrin Arabian * \\ Ali Mohammad Fazilatfar \\ Seyyed Mohammad Anooshe
}

Suggested Citation:

New Trends and Issues Proceedings on Humanities and Social Sciences.

Abstract

$p$

* Nasrin Arabian 
1. Introduction

\subsection{Research questions}

2. Review of literature 


\section{Methodology}

\subsection{Participants}

3.2. Materials

3.3. Data collection procedure

3.3.1. pre-test

3.3.2. treatment

3.3.3. post-test 


\subsection{Scoring and analysis procedure}

\section{Results}

\subsection{Inter rater reliability}

\subsection{Pre-test results}

$$
)
$$


Table 2. ANOVA Results of the 3 groups in the post-test

Table 3. Bonferroni test results of the $\mathbf{3}$ groups post-test

\section{Conclusion and discussion}




\section{Appendix}

\section{0}

1

2 


\section{References}

Journal, 62

Journal of Language Teaching and Research 2

Thought and knowledge: An introduction to critical thinking

TESL Journal, 11

Internet

International Journal of Linguistics 4

Journal 71

Asian EFL

Life

Critical Thinking: Tools for Taking Charge of Your Professional and Personal

The miniature guide to the art of asking essential questions. Based on critical thinking concepts and Socratic principles

The miniature guide to critical thinking: Concept and tools

. Review of Educational Research 66

System 40

Reason to write: Applying critical thinking to academic writing 